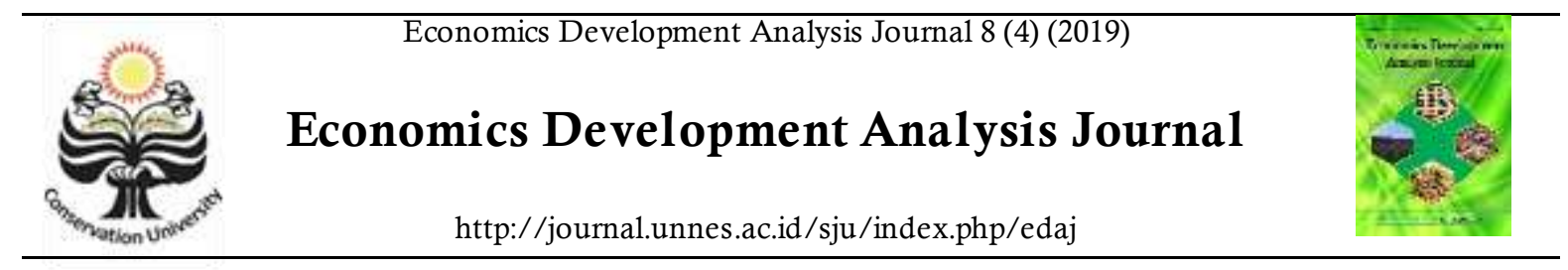

\title{
Street Vendor in Semarang: Structuring, Empowerment, and Welfare
}

\section{Eko Handoyo $^{1 \bowtie,}$ Iwan Hardi .S ${ }^{2}$}

${ }^{1,2}$ Political and Citizenship Department, Faculty of Social Sciences, Universitas Negeri Semarang

\begin{tabular}{ll}
\hline $\begin{array}{l}\text { Article } \\
\text { Information }\end{array}$ & Abstract \\
\hline Thistory of Article & $\begin{array}{l}\text { This study aims to analyse (1) Semarang City Government policies in managing and empowering } \\
\text { street vendors, (2) implementation of local regulations in managing and empowering street vendors, } \\
\text { and (3) the impact of implementing policies in structuring and empowering street vendors. for their } \\
\text { Received May 2019 }\end{array}$ \\
$\begin{array}{l}\text { Accepted July 2019 This research uses a qualitative approach and case studies and research takes place in South } \\
\text { Pusblished November } \\
\text { Batan and Penggaron. Data taken from observations, interviews, and literature studies. The results } \\
\text { of the study were analyzed with qualitative analysis techniques from Miles \& Huberman and } \\
\text { Creswell. From the research analysis and field findings, the following results were obtained. First, } \\
\text { the Semarang City Government manages and empowers Street Vendors by referring to regional } \\
\text { regulation No. 11 of 2000. Second, the structuring policy carried out by the city government only } \\
\text { focuses on the implementation of relocation and elimination of business locations. Empowerment } \\
\text { activities managed by the government are facilitating access to capital, business facilitation } \\
\text { assistance, trade facilities, institutional development, and limited promotion through creative } \\
\text { product exhibitions. Third, the policies on structuring and empowering street vendors have direct } \\
\text { and indirect impacts on the welfare of street vendors, especially in South Batan. Based on the results } \\
\text { of the study it is recommended that the arrangement of street vendors be carried out by taking into } \\
\text { account the interests of the community of road access and also paying attention to the future of street } \\
\text { vendors. }\end{array}$ \\
$\begin{array}{l}\text { Keywords: } \\
\text { Empowerment, Street } \\
\text { Vendors, Structuring, } \\
\text { Welfare }\end{array}$
\end{tabular}

${ }^{凶}$ Corresponding author :

Address: Sekaran, Gunungpati, Semarang City,

Central Java, 50229

E-mail: edaj@mailunnes.ac.id 


\section{INTRODUCTION}

Local governments in Indonesia, particularly in Semarang, faces urban problems. One of the problems is related to the informal sector and street vendors. The rapid growth of street vendors, especially unorganised or unregistered street vendors that occupy public spaces has caused the government to face a dilemma (Yuliani, 2012; Pratama dan I Gusti Wayan Murjana Yasa, 2018). On the one hand, local community intends to eliminate their existence to maintain the orderliness, cleanliness, and security of the public space (Swaracinta, 2013; Duwit, Veronica A. Kumurur, dan Ingerid L. Moniaga, 2015). On the other hand, Street Vendors who have already occupied public spaces must be organized and fostered, so that they continue to exist but do not disturb the public (Rini, 2012; Thoriq dan Samsudin, 2018). Thus, a policy must be made to solve this.

The related policy for Street Vendors should accommodate all parties interests. However, the current policy ignores the interests of Street Vendors, making many of them curbed, evicted, and relocated to a place that is not feasible to run a business. Moreover, the government takes repressive and brutal to sacrifice their existence (Ramli, 1992; Bromley, 2000). Many authorities in Africa, Asia, and Latin America complained about the presence of street vendors as a significant problem in their cities (Bromley, 2000). These merchants are targeted by the police and city government for the eviction and elimination (Bromley and Depdulal Saha, 2012). However, there are some reasons which make it difficult for the government to do that, which are the stubbornness of street vendors, rule violation, and the rights of public space consumption (Syam, 2016). The high number of wild merchants on the street makes the local regulation authorized by the local government of Indonesia ineffective (Saputra, 2010; Syam, 2016).

In Semarang, the government regulates policy regarding informal sector and street vendors in RTRW 2011-2031, RPJMD 2016 -
2021, and RKPD 2018, as well as in the Local Regulation Number 11 of 2000. With the issuance of Presidential Regulation Number 125 of 2012 and Minister of Home Affairs Regulation No. 41 of 2012, the city government also uses it as a reference in regulating, arranging, developing, and empowering street vendors. These local policies focus on educating the vendors regarding their rights and responsibilities. Besides that, the arrangement of Street Vendors is also included as the strategy of Semarang in realising the city as an international attraction.

To achieve the vision of Semarang as a city of Trade and services and to realize the SETARA program or Semarang Sejahtera (wealthy Semarang), the government conducts a physical arrangement of the city, by tidying the Simpang Lima roundabout, Pahlawan street, Pandanaran street, Ahmad Yani street, Gajahmada street, Pemuda street, Sutomo, Imam Bonjol street, Sugiyonopranoto street, and Tugu Muda roundabout. Likewise, on almost all roads, a pedestrian route is built. Following the RKPD of Semarang in 2018, to manage green open spaces, the Semarang city government conducts rehabilitation and construction of new parks targeted for 2018 to reach 276 locations.

In the context of the urban planning of Semarang, Street Vendors who occupy Pahlawan street were relocated to the other street centre since December 2010. At first, they insisted that they would not move, but after the government conducted socialisation and approaches, they were willing to move to Menteri Soepeno's street. In 2017 and 2018, Street Vendors who occupy the Center for Street Vendors in Menteri Soepeno street are forced to sell out of the streets because their shelter was going to be demolished for the benefit of the construction of the Great Indonesian Park, which is expected to end in October 2018. There are still many street vendors organised by the city government, such as Street Vendors in Kalisari, Barito, and Undip Imam Barjo (Pleburan).

Besides, there are still also many unregistered and unprotected street vendors in 
Kokrosono, Kartini street, Sayangan, Sampangan, and several occasional vendors in other places. Later, it is suspected that there is a different treatment shown by the Semarang city government towards Registered Street Vendors and Unregistered Street Vendors since unregistered street vendors can be evicted at any time.

The issuance of Presidential Regulation Number 125 of 2012 and Minister of Home Affairs Regulation No. 41 of 2012 should have been followed up by the Semarang City Government to organise and empower Street Vendors. The local regulation only regulates the guidance of Street Vendors on the issues of rights, obligations, prohibitions, and supervision. Lately, it is expected that comprehensive structuring and empowerment efforts as regulated by the administrative regulation and the Minister of Home Affairs regulations above have not been implemented optimally. These issues attracted the researcher to discuss, primarily to examine the extent to which the policy of structuring and empowering street vendors is carried out after the issuance of Presidential Regulation No. 125 and Minister of Home Affairs Regulation No. 41 of 2012. In accordance with the research problems, the following description will explain and analyze (1) the Semarang City Government's policy in managing and empowering Street Vendors, (2) the implementation of the Semarang City Government policy in managing and empowering Street Vendors, and (3) the impact of the implementation of the policy of structuring and empowering street vendors on street vendor's welfare. Before the results of the study were presented, a literature review which discussed the positive and negative aspects of the relocation policy for street vendors and research methods was first presented, which included the used approach, the location of the study, the unit of analysis, data collection techniques, data validity, and data analysis technique.

The existence of the informal sector in Indonesia is increasing due to its existence as a place for workers who do not have diplomas and skills needed in the formal sector. This also happens in other developing countries (DeLuca, 2012; Handoyo, 2012; Handoyo, 2018; ODI, 2008; Muthusamy and M. Syed Ibrahim, 2016; Wilonoyudho, 2014; Zlolnisky, 1994). The informal sector becomes an alternative employment when the development program is unable to provide employment opportunities in the formal sector (Dimas, 2008 in Brotosunaryo, Wahyono, and Sariffudin, 2013). One of the informal sectors activities is street trade, which is generally dominated by food and beverage traders as well as kitchen, cleaning, agriculture, carpentry, and automotive spare parts providers. In Semarang, culinary street vendors are more dominant than other informal sector economic activities. Their presence is mainly seen at night.

Increasing urban infrastructure provides an attraction for workers from rural and satellite cities to seek fortune by working in the informal sector. The number of casual sector workers in Central Java as of February 2014 was 62.06\% (Central Java Province BPS, 2014). The increasing number of workers in the informal sector has led local governments to make policies by making arrangements so that the existence of these workers does not disturb or violate the public space that has been designed for use by local governments through Spatial Planning and Regional Planning (RTRW).

Public policy is known as "whatever government chooses to do or not to do (Dye, 2002). The policy taken by the city government is based on the choice to do something or not do something for the sake of communal benefit. The policy for informal sector workers is a part of government policy, especially concerning economic and employment policies. Government policies towards public space have different implications. The increasing number of land used by Semarang city government for specific functional interests, starting from green open spaces, reservoirs, lakes, pedestrian roads, city parks, and others, will urge street vendors to build their business. On the other hand, the development of the city will also give birth to new street vendors who want to get lucky looking for 
sustenance from the development of the city (Handoyo, 2012).

The structuring policy for street vendors should not only be intended to organise public spaces but also pay attention to the future of street vendors. Many local governments pay serious attention to structuring and empowering street vendors, which has a positive impact on the continuity of business and the future of street vendors. Some studies provide information about the positive impact of the Street Vendor arrangement policy. Fatnawati (2013) in a study of the Impact of Street Vendors Relocation based on the City of Surakarta Regional Regulation Number 3 of 2008 concerning Management of Street Vendors for Street Vendors in Surakarta concluded that street vendors, after being relocated, gained certainty in running their businesses.

However, it is recognised that the distribution of kiosks which do not match the type of merchandise make it difficult for street vendors to adapt. Purnomo (2018) in his research on the Impact of Relocation on the Social Environment of Street Vendors in the Pratistha Harsa Purwokerto Culinary Center concluded that after relocation, street vendors in trading felt easier, safer and cleaner. Nurvitasari (2014) in a study on the Arrangement of Street Vendors to Provide Legal Protection and Improvement in Traders' Living Levels (Case Study in the Manahan Solo Area) concluded that Manahan Street Vendors gained certainty and comfort in running a business because they got a decent place and given regular guidance. From some of the results of research on street vendors, it can be concluded that street vendors get a safer and more comfortable new location that is not likely to be transferred again by the local government because it is under the spatial plan prepared by the local government.

The street vendor arrangement policy, especially the relocation of street vendors, actually had unfavourable impacts on street vendors. The following research provides data on the negative impact of the Street Vendor arrangement policy on the future of Street
Vendors. Prasetya and Fauziah's (2016) study on the Impact of Street Economic Relocation of Street Vendors in Buduran Subdistrict, Sidoharjo Regency showed that street vendors income decreased by $20 \%$ due to a lack of empowerment from local governments. Syakir (2017) in his research on the Analysis of the Impact of Relocation and Revitalization of Street Vendors from Jalan Sabang to the Elpabes Surakarta Market Area concluded that after relocating, the turnover of street vendors decreased to $26.35 \%$. Likewise, the profits obtained by street vendors decreased by $26.1 \%$. This is caused by the kiosk position which is not immediately visible to the buyer, and the number of visitors has declined. Sawitri (2015) in his research on the Analysis of the Arrangement of Street Vendors in Maros Regency concluded that the Street Vendor policy could have a positive and negative impact. The negative impact of the Street Vendor arrangement in Maros is the act of defiance of Street Vendors, which is still selling on the side of the road because the new location is far from visitors. Andrianto (2012) in a study on the Implementation of Street Vendors Relocation Policy Evaluation behind the Eleven March University Campus in Surakarta concluded that the relocation of street vendors resulted in a drastic decline in income. This is because the location of the Stage Rejo market is less strategic and far from buyer access. From the various studies, information can be obtained that the negative impacts of relocation are (1) the new location is not strategic for the buyer to visit and (2) there is a decrease in the income of street vendors.

\section{RESEARCH METHODS}

This study employed a qualitative approach and case studies. The research concerned on Street Vendors in Batan Selatan and Barito (were moved to Penggaron). The analysis focused on the Street Vendors and Trade Service. The study employed purposive random sampling. Besides, because of the complexity of the problems, 25 street vendors were made as respondents. To obtain data on government 
policy towards street vendors, the research took the data from the interview with three employees of Semarang Market Officials. Overall, the data from the analysis were made by interview, observation, and literature study. Interviews were conducted in an unstructured manner where the researcher does not use interview guidelines that have been wholly and systematically compiled, but in the form of outlines of research questions according to the research problems (Sugiyono, 2009). In this study, observations were made by direct observation to respondents and informants (Sugiyono, 2009). Things that cannot be taken with these two techniques are carried out by literature study. To measure the validity of the data, triangulation was also used (Miles \& Huberman, 1992; Moleong, 2007). The use of triangulation is useful for solving potential problems regarding the construct of validity (Yin, 1997).

Triangulation method was chosen by comparing the results of interviews with the results of observations, mainly related to structuring and empowerment policies carried out by the regional Regulatory Agency and the impact of these policies on the welfare of Street Vendors. The results of the study were analysed by interactive qualitative analysis techniques, with cycles of data collection, data reduction, data presentation and conclusions and verification (Miles \& Huberman, 1992). To deepen the analysis, data analysis was also conducted according to Creswell, namely (1) organizing data, (2) reading and making memos, (3) describing, classifying, and interpreting data into codes and themes, (4) presenting and visualizing (Creswell, 2015).

\section{RESULTS AND DISCUSSION}

This part This research was conducted in two locations, which are the Centre of Street Vendors in Batan Selatan and Penggaron. The findings of the study only concerned about these areas. The result was unable to be generalised to other cities in Semarang. The following data are the respondents of the research.
Based on the table above, the Street Vendors in Batan Selatan consists of 10 (40\%) food sellers. Meanwhile, the vendors in Penggaron had $15(60 \%)$ vendors selling automotive spare parts and accessories. The merchants in Batan Selatan offer various products, including foods, like fried rice, nasi rames, nasi langgi, Padang food, as well as beverages, such as soft-serve ice cream, juices, and coconut drink. The high number of culinary street merchants is understandable since it is more lucrative to sell foods and beverages to Semarangese who tends to dine out of their house. The local interest boosts the business of street food in Semarang. Meanwhile, the merchant in Penggaron which is used to be known as Barito maintains its mainstream of working in the fields of automotive repair and accessories. However, there is still a lack of vehicle spare parts dealer in the area due to (1) government's priority of focusing the area for trading only motorcycle spare parts and accessories, and (2) the unreadiness of the infrastructure for the dealers.

From the findings, the researchers obtained several things to conclude. First, the government of Semarang has already empowered the street vendors according to the Local Regulation Number 11 Year 2000, Presidential Regulation Number 125 Year 2012, and The Regulation of Ministry of Internal Affairs Number 41 Year 2012. In details, the central regulation from the President and Ministry of Internal Affairs should become the guidance for the new Local Regulation. Thus, Semarang's officials regulated the Local Regulation Number 11 Year 2000 to only focus on organising and guide the street merchants. They also educate the vendors to be informed for their rights and do their responsibility. The only lacking point on the regulation is the empowerment to the vendors.

Second, the organisation of the government only concerns on collecting the data from locals and registering the vendors into their database in a more approachable way. They also focus on the relocation and elimination of the 
Eko Handoyo \& Iwan Hardi. S/ Economics Development Analysis Journal 8 (4) (2019)

vendors. Besides, they also cooperate to the other local government and business partners to maximally execute the organisation. The program has been included in the Government
Work Plan of Semarang in 2018. In spite of that, there is no follow-up action conducted by the officials.

Table 1. The Respondents viewed from Education, Origins, Fields of Entrepreneurship, and Income

\begin{tabular}{|c|c|c|c|c|c|c|c|c|c|}
\hline No & Name & Age & Genre & Location & Education & $\begin{array}{l}\text { City of } \\
\text { Origin }\end{array}$ & $\begin{array}{l}\text { Fields of } \\
\text { Entrepreneurship }\end{array}$ & $\begin{array}{l}\text { Family } \\
\text { Members }\end{array}$ & $\begin{array}{l}\text { Daily } \\
\text { Income }\end{array}$ \\
\hline 1 & ES & 36 & Male & $\begin{array}{l}\text { Batan } \\
\text { Selatan }\end{array}$ & $\begin{array}{l}\text { Vocational } \\
\text { High } \\
\text { School }\end{array}$ & Semarang & Fried Rice & 3 & 150.000 \\
\hline 2 & SP & 52 & Female & $\begin{array}{l}\text { Batan } \\
\text { Selatan }\end{array}$ & $\begin{array}{l}\text { Senior } \\
\text { High } \\
\text { School }\end{array}$ & Semarang & Nasi Rames & 2 & 300.000 \\
\hline 3 & YS & 24 & Male & $\begin{array}{l}\text { Batan } \\
\text { Selatan }\end{array}$ & $\begin{array}{l}\text { Vocational } \\
\text { High } \\
\text { School }\end{array}$ & Semarang & Juices & 2 & 200.000 \\
\hline 4 & $\mathrm{R}$ & 53 & Male & $\begin{array}{l}\text { Batan } \\
\text { Selatan }\end{array}$ & Unfinished & Semarang & $\begin{array}{l}\text { Mixed } \quad \text { Fruit } \\
\text { Juices }\end{array}$ & 5 & 700.000 \\
\hline 5 & A & 42 & Female & $\begin{array}{l}\text { Batan } \\
\text { Selatan }\end{array}$ & $\begin{array}{l}\text { Elementary } \\
\text { School }\end{array}$ & Semarang & $\begin{array}{l}\text { Molen and Onde- } \\
\text { onde }\end{array}$ & 4 & 100.000 \\
\hline 6 & JW & 51 & Male & $\begin{array}{l}\text { Batan } \\
\text { Selatan }\end{array}$ & $\begin{array}{l}\text { Middle } \\
\text { School }\end{array}$ & Semarang & $\begin{array}{l}\text { Padang food and } \\
\text { Coconut Drink }\end{array}$ & 3 & 200.000 \\
\hline 7 & $\mathrm{IJ}$ & 44 & Female & $\begin{array}{l}\text { Batan } \\
\text { Selatan }\end{array}$ & $\begin{array}{l}\text { Senior } \\
\text { High } \\
\text { School }\end{array}$ & Semarang & $\begin{array}{l}\text { Nasi Langgi and } \\
\text { Chicken }\end{array}$ & 2 & 200.000 \\
\hline 8 & ES & 52 & Male & $\begin{array}{l}\text { Batan } \\
\text { Selatan }\end{array}$ & $\begin{array}{l}\text { Senior } \\
\text { High } \\
\text { School }\end{array}$ & Semarang & Lamb satay & 2 & 400.000 \\
\hline 9 & $S$ & 54 & Female & $\begin{array}{l}\text { Batan } \\
\text { Selatan }\end{array}$ & $\begin{array}{l}\text { Senior } \\
\text { High } \\
\text { School }\end{array}$ & Semarang & $\begin{array}{l}\text { Fruit soup and } \\
\text { Fried sausage in } \\
\text { egg rolls }\end{array}$ & 3 & 700.000 \\
\hline 10 & SR & 54 & Female & $\begin{array}{l}\text { Batan } \\
\text { Selatan }\end{array}$ & $\begin{array}{l}\text { Vocational } \\
\text { High } \\
\text { School }\end{array}$ & Semarang & $\begin{array}{l}\text { Soft-served ice } \\
\text { cream }\end{array}$ & 2 & 500.000 \\
\hline 11 & $\mathrm{Rt}$ & 56 & Male & Penggaron & $\begin{array}{l}\text { Elementary } \\
\text { School }\end{array}$ & $\begin{array}{l}\text { Mranggen } \\
\text { Demak }\end{array}$ & $\begin{array}{l}\text { Spare parts of } \\
\text { Motorcycle }\end{array}$ & 1 & 150.000 \\
\hline 12 & MA & 26 & Male & Penggaron & $\begin{array}{l}\text { Vocational } \\
\text { High } \\
\text { School }\end{array}$ & Rembang & $\begin{array}{l}\text { Automotive } \\
\text { Modification }\end{array}$ & 3 & 500.000 \\
\hline 13 & Sy & 64 & Male & Penggaron & $\begin{array}{l}\text { Elementary } \\
\text { School }\end{array}$ & Klaten & $\begin{array}{l}\text { Machine Lathe } \\
\text { service }\end{array}$ & 6 & 750.000 \\
\hline 14 & $\mathrm{Bn}$ & 48 & Male & Penggaron & $\begin{array}{l}\text { Elementary } \\
\text { School }\end{array}$ & Semarang & $\begin{array}{l}\text { Automotive } \\
\text { Repair Shop }\end{array}$ & - & 400.000 \\
\hline 15 & DW & 60 & Male & Penggaron & $\begin{array}{l}\text { Middle } \\
\text { School }\end{array}$ & Semarang & $\begin{array}{l}\text { Automotive } \\
\text { AccessoriesShop }\end{array}$ & - & 200.000 \\
\hline 16 & MAS & 19 & Male & Penggaron & $\begin{array}{l}\text { Vocational } \\
\text { High } \\
\text { School }\end{array}$ & Semarang & $\begin{array}{l}\text { Automotive } \\
\text { Repair Shop }\end{array}$ & - & 70.000 \\
\hline 17 & JS & 35 & Male & Penggaron & $\begin{array}{l}\text { Vocational } \\
\text { High } \\
\text { School }\end{array}$ & Klaten & $\begin{array}{l}\text { Motorcycle Tire } \\
\text { Pump }\end{array}$ & 3 & 100.000 \\
\hline 18 & $\mathrm{BR}$ & 67 & Male & Penggaron & $\begin{array}{l}\text { Vocational } \\
\text { High } \\
\text { School }\end{array}$ & Pemalang & $\begin{array}{l}\text { Automotive } \\
\text { Spare Parts Shop }\end{array}$ & 2 & 300.000 \\
\hline
\end{tabular}




\begin{tabular}{|c|c|c|c|c|c|c|c|c|c|}
\hline 19 & Dd & 67 & Male & Penggaron & $\begin{array}{l}\text { Middle } \\
\text { School }\end{array}$ & $\begin{array}{l}\text { Mranggen } \\
\text { Demak }\end{array}$ & $\begin{array}{l}\text { Automotive } \\
\text { Spare Parts Shop }\end{array}$ & 3 & 120.000 \\
\hline 20 & Iw & 50 & Male & Penggaron & $\begin{array}{l}\text { Senior } \\
\text { High } \\
\text { School }\end{array}$ & Semarang & $\begin{array}{l}\text { Automotive } \\
\text { AccessoriesShop }\end{array}$ & 5 & 150.000 \\
\hline 21 & $\mathrm{Cp}$ & 48 & Male & Penggaron & $\begin{array}{l}\text { Vocational } \\
\text { High }\end{array}$ & Semarang & $\begin{array}{l}\text { Automotive } \\
\text { AccessoriesShop }\end{array}$ & 2 & 150.000 \\
\hline 22 & AS & 34 & Male & Penggaron & $\begin{array}{l}\text { School } \\
\text { Vocational } \\
\text { High } \\
\text { School }\end{array}$ & Semarang & $\begin{array}{l}\text { Automotive } \\
\text { AccessoriesShop }\end{array}$ & 4 & 80.000 \\
\hline 23 & $\mathrm{Tf}$ & 29 & Male & Pengaron & $\begin{array}{l}\text { Vocational } \\
\text { Diploma }\end{array}$ & Klaten & $\begin{array}{l}\text { Automotive } \\
\text { Spare Parts Shop }\end{array}$ & 2 & 100.000 \\
\hline 24 & SW & 62 & Male & Penggaron & $\begin{array}{l}\text { Vocational } \\
\text { Diploma }\end{array}$ & Semarang & $\begin{array}{l}\text { Automotive } \\
\text { AccessoriesShop }\end{array}$ & - & 1.000 .000 \\
\hline 25 & $\mathrm{TP}$ & 49 & Male & Penggaron & $\begin{array}{l}\text { Senior } \\
\text { High } \\
\text { School }\end{array}$ & Semarang & $\begin{array}{l}\text { Automotive } \\
\text { Spare Parts Shop }\end{array}$ & 1 & 200.000 \\
\hline
\end{tabular}

Source : Data Processed

Third, despite its existence as the follow up from the President and Ministry's regulation, the government still organises empowering activities for the registered or unregistered sellers without any legal control from official regulation. The activities are accessed facilitation to capital (although it attracts no vendors), business site, and infrastructure (cart); institutional empowerment (community empowerment for Street Vendors); and limited promotion through creative product fair. In the meantime, the unstructured empowering activities are a business enhancement, production increase, processing of products, and technical guidance. The limited budget for the Market Officials and the increasing number of unregistered Street Merchants has weakened those attempts to be executed well.

Fourth, the policy of organising and empowering local vendors, specifically street vendors in Batan Selatan and Penggaron impacts them directly or indirectly. The placement of street vendors in Batan Selatan which is in the crowds' area and the provision of facilities, like access to capital, business site and infrastructure, promotion and institutional empowerment has improved the business. The relocation of the business from Barito to Penggaron also impacted the vendors to have improved welfare. Their new location is still organised, having an incomplete facility, and geographically distant from the centre of the city.

A good city should be able to be a good living place for its citizen. A global declaration of the World Health Organization has resulted in the healthy cities movement. A parameter of a healthy city is based on its social and economic justice (Newman \& Jennings, 2014). A city with such justice can eliminate its case of poverty as the priority of social, ethical, and environmental as well as to motivate the human to live in equality and harmony.

Semarang is a metropolitan city which is categorised as Healthy City. The status means that the city can provide its citizen freedom of doing an economic activity which allows the development of human's quality. Moreover, through various programs of eliminating poverty are summarised through an integrated program of health, economy, education, infrastructure, and environment. The program is called gerdu kempling. Through this program, it is expected that the number of poverty will be reduced to 398.009 people in 2009. Despite the increase to 448.398 in 2011, the number is the smallest amongst all cities in Central Java (Kertati, 2013).

Most citizens in the urban or rural area, whether from the village or the corner part of the city, are having no skill to work in formal sectors. Most of them decided to work in the informal 
sector. Based on the data of Wilonoyudo, as in Kertati (2013), the number of citizens in Semarang who work in informal sectors is $81.9 \%$. The number includes the owners of Street Vendors which increase annually. In 2009, it reached 11.414, while in 2012, the number rose to 11.981 or simply, there was an increase of 567 vendors in 3 years. According to the data of Market Officials, the number of sellers decreased to 6.315 in 2015. However, there is a possible increase in 2018 along with the increasing number of crowd attracting place in Semarang.

The active policy of Semarang's government and other informal sector become the reasons why the increasing number of Street Vendors in Semarang heavily occurs. Between 2000 to 2014, the policy of Semarang's government is considered unsupportive to economically weak parties. Therefore, many street vendors, including in Sampangan, Basudewo, Kokrosono, Pahlawan street, Kartini street, and Karyadi hospital were evicted from its place. The event resulted many people lost their job and unable to work or run their business.

Most registered street merchants in Batan Selatan and Barito (which is moved to Penggaron) are not affected by the regulation. They are still running their business well without any threats coming from Municipal Police or Thugs. They have already got their place. In Penggaron, the sellers have been mostly placed through the facilities are still in an ongoing development process. The regulation which is run by the government brings effects to the Street Vendors. The rule affects their income which can make them afford their needs, such as buying secondary needs, like a car, motorcycle, television, refrigerator, etc. Some of the street vendors have already included into local street vendors association which is promoted by the local government. They are also sponsored by the government which helps them to improve their capital or to expand their business.

In the perspective of implementation theory, George C. Edward III views that from the aspects of communication, resources, disposition, and bureaucracy, the existence of
Street vendors in Batan Selatan and Penggaron are influenced from the excellent discussion of the regulator, professional human resources, firm commitment of street vendors organization, and institution of bureaucracy (which is the Ministry of Trade) which have clear Standard Operating Procedures for their empowerment. The wellimplemented policy can be seen from the significances which are suitable for most of the society (Nawawi, 2009). The significances cope (1) the existence of the street vendors and (2) the welfare of the street vendors.

\section{CONCLUSION}

From the findings, there are four points to conclude. First, the government of Semarang has already empowered the street vendors according to the Local Regulation Number 11 Year 2000, Presidential Regulation Number 125 Year 2012, and The Regulation of Ministry of Internal Affairs Number 41 Year 2012. They also educate the vendors to be informed for their rights and do their responsibility. Second, the organisation of the government only concerns on collecting the data from locals and registering the vendors into their database in a more approachable way. They also focus on the relocation and elimination of the vendors. Besides, they also cooperate to the other local government and business partners to maximally execute the organisation. Third, despite its existence as the follow up from the President and Ministry's regulation, the government still organises empowering activities for the registered or unregistered sellers without any legal control from official regulation. The activities are accessed facilitation to capital (although it attracts none vendors), business site, and infrastructure (cart); institutional empowerment (community empowerment for Street Vendors); and limited promotion through a visit to Semarang and Great Sale fair. Fourth, the policy of organising and empowering local vendors, specifically street vendors in Batan Selatan and Penggaron impacts them for their income, basic needs, and future investment.

There are also some recommendations to suggest. First, the organisation of Street Vendors 
should be done comprehensively according to Presidential Regulation Number 125 the Year 2012 and The Regulation of Ministry of Internal Affairs Number 41 the Year 2012. The policy should not focus on the relocation and eviction, but also the development of the areas, considering the increasing number of the Street Vendors. Second, the policy of Street Vendor empowerment should be based on these policies aforementioned. The activities should be related to facilitation and infrastructure development, capital access, entrepreneurship skills, production increase, management, networking session, promotion, and technical guidance since this stuff will signify the impact to the vendors. Third, the local government in Semarang should limit the permission to the investor who develops retail and hotel business, since they should protect the street vendors, and there has been very much number of it.

\section{REFERENCES}

Andrianto, Novan. 2012. "Evaluation of the Implementation of the Street Vendor Relocation Policy (PKL) behind the Sebelas Maret University Campus in Surakarta." Thesis in the Department of Administrative Sciences, Faculty of Social and Political Sciences, Sebelas Maret University, Surakarta.

BPS of Central Java Province. 2014. Official Statistics of Central Java BPS Statistics No. 31/05/33/ Th. VIII, May 5, 2014. P. 1-7

Bromley, Ray. 2000. "Street Vending and Public Policy: a Global Review". In The International Journal of Sociology and Social Policy Volume 20 Number 1/2 2000 pp.1-28.

Brotosunaryo, P.M., Hadi Wahyono, and Sariffudin. 2013. "Semarang City's Informal Sector Structuring and Development Strategy." In Riptek Vol. 7 No. 2 of 2013 p. 71-80.

Creswell, J. W. (2015). Qualitative Research \& Research Design Choose Among Five Approaches. Yogyakarta: Student Library.

DeLuca, Joseph S. 2012. "Street Vendors in the Global City: Exploring Genoa's Informal Economy." In The JUE, Vol. 2, Issue 1, 2012, p. 1-11

Duwit, Beatrix S., Veronica A. Kumurur, and Ingerid L. Moniaga. 2015. "The Perception of Street Vendors towards the Selling Area Along Jalan Pasar Pinasungkulan Karombasan Manado."
In Sabua Vol. 7, No. 2, October 2015. Pg. 419428 .

Dye, Thomas R. 2002. Understanding Public Policy Tenth Edition. New Jersey: Presntice Hall.

Fatnawati, Nur. 2013. "The Impact of Relocation of Street Vendors based on Surakarta City Regulation Number 3 of 2008 concerning Management of Street Vendors on the Street Vendors Business in Surakarta." Thesis onLaw Study Program, Faculty of Law, Semarang State University.

Handoyo, Eko. 2012. "The Existence of Street Vendors Study on the Contribution of Social Capital to PKL Resistance in Semarang." The SWCU Salatiga Development Study Doctorate Dissertation Program. Unpublished.

Handoyo, Eko. 2012. Public Policy. Semarang: Widya Karya.

Handoyo, Eko. 2018. Street Vendors (PKL) as The Survival Strategy of Poor Community. "In Trace Journal of Economics and Development Vol. II (1) (2018): 173-188. Kertati, Indra. 2013." Semarang City Poverty Analysis based on Data Collection of Social Protection Program (PPLS) ". In Riptek Vol.7, No.1 Year 2013 Pages 27-38.

Miles, Mattheuw B. And A. Michael Huberman. 1992. Qualitative Data Analysis. Tjetjep Rohendi Rohidi's translation. Jakarta: UI Press.

Moleong, Lexy J. 2007. Qualitative Research Methods. Bandung: PT Youth Rosdakarya.

Muthusamy, A. and M. Syed Ibrahim. 2016. "Informal Workers, Informal Labor Market, Unorganized Workers' Social Security Act, Issues and Challenges." In RESEARH PAPER, Vol. 6, Issue 4, April 2016, pp. 37-39.

Nawawi, Ismail. 2009. Public Policy Analysis, Theory and Practice Advocacy Strategies. Surabaya: PMN.

Newman, Peter and Isabella Jennings. 2014. Cities as Sustainable Ecosystems. Suriptono translation. Malang: Bayumedia Publishing.

Nurvitasari. 2014. "Arrangement of Street Vendors to Provide Legal Protection and Increase Traders' Living Standards (Case Study in Manahan Solo Area)." In Jurisprudence, Volume 4, Number 2, September 2014, pages 108-114.

ODI. 2008. Briefing Paper 44, November 2008, pp. 14.

Prasetya, Mochammad Aringga and Luluk Fauziah. 2016. "Socio-Economic Impacts of Street 
Vendors Relocation (PKL) in Buduran District, Sidoarjo Regency." in JKMP Vol. 4, No. 2, September 2016, 117-234.

Pratama, I Gede Risky and I Gusti Wayan Murjana Yasa. 2018. "The Elasticity of Chili Prices and Income of Street Vendors in Denpasar City."In e-Journal EP UNUD, 7 (9): 1983-2010.

Purnomo, Rochmat Aldy. 2013. "The Impact of Relocation on the Social Environment of Street Vendors in the Pratistha Harsa Purwokerto Culinary Center." In the Journal of Equilibrium, Volume 11, Number 1, March 2016, Page 1-9.

Ramli, Rusli. 1992. Urban Informal Sector Street Vendors. Jakarta: Ind-Hill-Co.

Rini, Hartati Sulistyo. 2012. "The Dilemma of the Existence of the Informal Sector." In COMMUNITY 4 (2), (2012): 200-209.

Saputra, Rio. 2010. "Planning and Implementation of Street Street Merchandising Policy by Pekanbaru Market Agency (Case Study of the Senapelan Market)." Thesis in the Department of State Administration, Faculty of Economics and Social Sciences, UIN Sultan Syarif Kasim Riau Pekanbaru.

Safitri, Nursamsi Dwi. 2015. "Analysis of Structuring Street Vendors in Maros Regency." Thesis on Government Study Program, Faculty of Social and Political Sciences, Hasanudin University, Makassar.

Sugiyono 2009. Educational Research Methods Quantitative, Qualitative, and R\&D Approaches. Bandung: Alfabeta.

Swaracinta 23 / Year II / January-February 2013, p. 6-9.

Syakir .2017. "Impact Analysis of Relocation and Revitalization of Street Vendors from the Sabang Road Area to the Surakarta Elpabes Market Area." Thesis on Islamic Economics Study Program, Faculty of Islamic Economics and Business, UIN Sunan Kalijaga Yogyakarta.
Syam, Nurul Azizah. 2016. "Implementation of Local Government Policy in Guiding Street Vendors (Case Study on Street Vendors in Palopo Village, Panakukang District, Makassar City)." Thesis on Political and Governmental Science Study Program FISIP Hasanudin University, Makassar.

Thoriq, M. Isa and Muchamad Samsudin. 2018. "

The Dilemma of the Street Vendor Relocation Policy (PKL) to the Blauran II Market in Salatiga City. "Journal of Management and Public Policy Vol. 3, No. 2, October 2018, p. 76-84.

Wilonoyudho, Saratri. 2014. "Migration and Involution in the City of Semarang." In the Journal of Humans and the Environment Vol. 21 No. 1, March 2014, p. 114-120.

Yin, Robert K. 1997. Case Study (Design and Method). Translation of M. Djauji Mudzakir. Jakarta: PT. Raja Grafindo Persada.

Yuliani, Sri. 2012. "Sustainability Analysis of Street Vendors Relocation Policy (PKL) in Surakarta City." In Public Spirit, Vol. 8, No. 2, October 2012, p. 63-82.

Zlolniski, Christian. 1994. "The Informal Economy in an Advanced Industrialized Society: Mexican Immigrant Labor in Silicon Valey." in Yale Law Journal, Vol. 103, Issue 8, 2305-2335. 